\title{
Energy consumption of low-energy consumption residential building retaining structure based on DeST analysis
}

\author{
GUO Hui Jin ${ }^{1, a^{*}}$, LI Yuan Qi ${ }^{2, b}$ \\ ${ }^{1}$ Architecture and civil engineering school, inner mongolia university of science and technology, \\ baotou, inner mongolia, 014010, china \\ ${ }^{2}$ Architecture and civil engineering school, inner mongolia university of science and technology, \\ baotou, inner mongolia, 014010, china \\ ajinguohuimba@163.com, bqly19850201@163.com
}

Keywords: DeST. Residential construction. Retaining structure. Building energy consumption.

Abstract. By DeST simulation software to build a residential construction in Inner Mongolia autonomous region, on the basis of without thermal insulation layer, one by one, change the retaining structure of exterior wall, roof, Windows and window wall ratio, build heat load value when simulating the factors changed, points out that the palisade structure factors impact on building energy consumption in size.

\section{Introduction}

In this paper, analyzing influence factors of retaining structure energy consumption by the cold area of Inner Mongolia a residential building, using DeST software mainly for building exterior wall, roof, Windows, window wall ratio factors such as in-depth analysis.

\section{Construction profiles and building a model}

Taking a residential building in the Inner Mongolia Autonomous Region as a simulation object. The residential building is 6 story brick structure, the height is $3 \mathrm{M}$, the north-south direction, the direction of the window wall ratio are 0.4 and 0.3 , building area is $2103.32 \mathrm{~m}^{2}$. Enclosure structure are shown in Table 1. Building plane diagram shown in Figure 1.

Table 1 Building envelope construction table

\begin{tabular}{|c|c|c|}
\hline Category & Construction & $\begin{array}{c}\text { Heat Transfer } \\
\text { Coefficient } \mathrm{W} /\left(\mathrm{m}^{2} \cdot \mathrm{K}\right) \\
\end{array}$ \\
\hline Roof & $\begin{array}{l}6 \mathrm{~mm} \text { Asphalt felt }+20 \mathrm{~mm} \text { Cement mortar } \\
+120 \mathrm{~mm} \text { Reinforced concrete }\end{array}$ & 3.47 \\
\hline Floor & $\begin{array}{l}\text { 20mm Cement mortar }+120 \mathrm{~mm} \text { Reinforced } \\
\text { concrete }+20 \mathrm{~mm} \text { Cement mortar }\end{array}$ & 2.86 \\
\hline Outer Wall & $\begin{array}{l}20 \mathrm{~mm} \text { Cement mortar }+240 \mathrm{~mm} \text { Reinforced } \\
\text { concrete }+20 \mathrm{~mm} \text { cement mortar }\end{array}$ & 1.74 \\
\hline Interior Wall & $\begin{array}{l}20 \mathrm{~mm} \text { Cement mortar }+180 \mathrm{~mm} \text { Ceramsite } \\
\text { concrete wall }+20 \mathrm{~mm} \text { Cement mortar }\end{array}$ & 2.02 \\
\hline Door & Single wooden door & 2.50 \\
\hline Interior Wall & Ordinary single-layer glass Windows & 5.70 \\
\hline
\end{tabular}

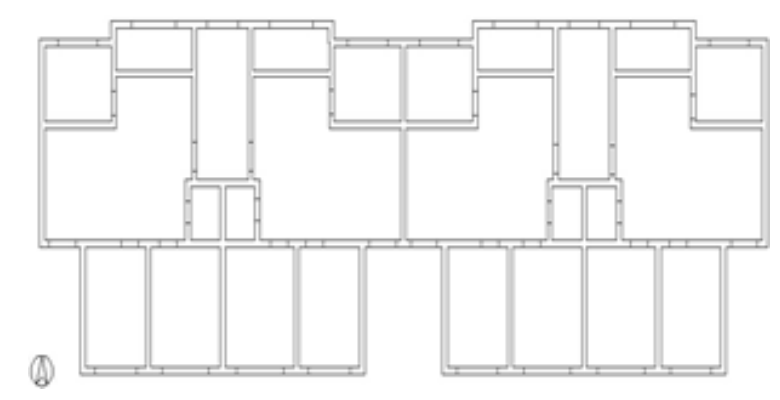

Figure 1 Benchmark floor plan 


\section{Parameter setting and simulation}

Meteorological parameters setting. The bulb temperature statistics Inner Mongolia area every day shown in Figure 2. Calculated by the average temperature relates to the heating period is $18^{\circ} \mathrm{C}$. Select the Inner Mongolia Ji LanTai for typical meteorological year.

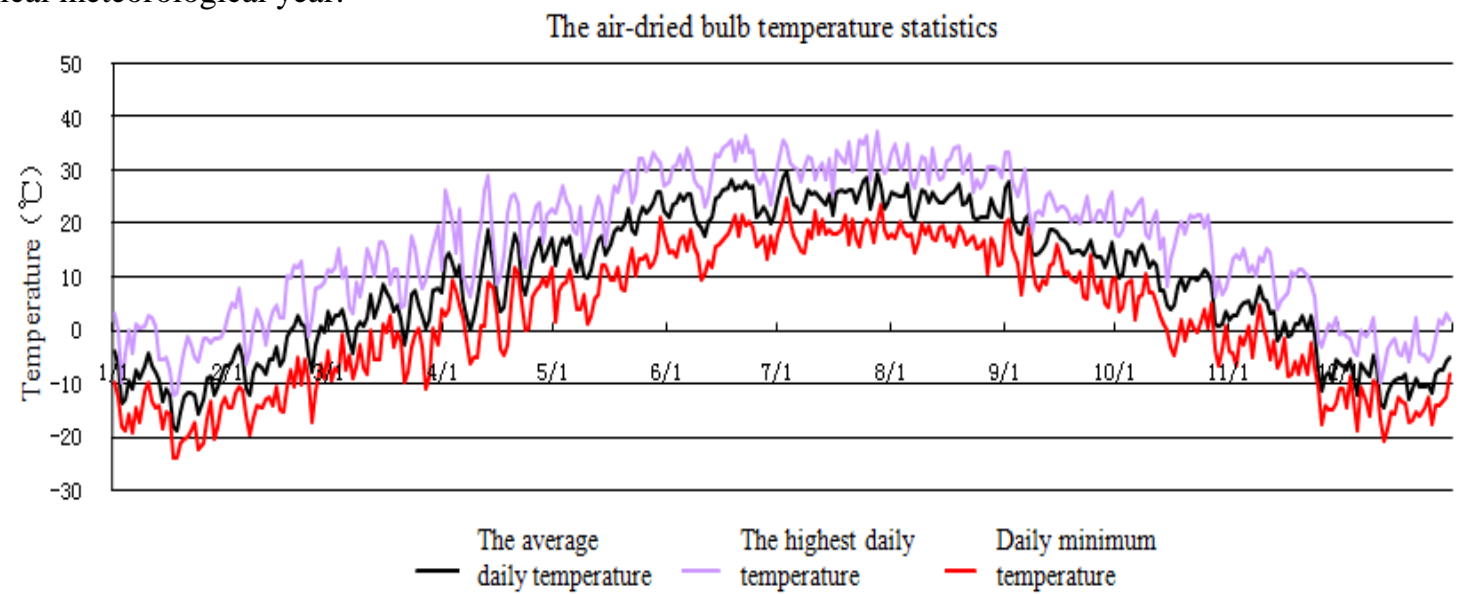

Figure 2 The air-dried bulb temperature statistics of Inner Mongolia region

Inside the room heat disturbance parameters setting. Every household room contains the main bedroom, second bedroom, guest room, living room, kitchen and bathroom. The per capita quantity of heat is $53 \mathrm{~W} / \mathrm{m}^{2}$. Bedroom and living room lighting the maximum heating capacity of $5 \mathrm{~W} / \mathrm{m}^{2}$. The living room equipment maximum heating capacity of $9.3 \mathrm{~W} / \mathrm{m}^{2}$. The largest heat kitchen equipment for $48.2 \mathrm{~W} / \mathrm{m}^{2}$.

System setting. In this simulation, The living room air conditioning starting specified in Table 2. Table 2 Each room different time air conditioner start-stop

\begin{tabular}{|c|c|c|c|c|}
\hline $\begin{array}{ll}\text { Room Type } & \text { Time }\end{array}$ & \multicolumn{2}{|c|}{ Weekdays } & \multicolumn{2}{|l|}{ Weekend } \\
\hline $\begin{array}{c}\text { Bedroom Air Conditioner } \\
\text { Start-stop }\end{array}$ & $\begin{array}{c}1: 00-7: 00 \\
8: 00-20: 00 \\
21: 00-24: 00\end{array}$ & $\begin{array}{c}100 \% \\
0 \% \\
100 \%\end{array}$ & $\begin{array}{c}1: 00-7: 00 \\
8: 00-11: 00 \\
12: 00-14: 00 \\
14: 00-20: 00 \\
21: 00-24: 00\end{array}$ & $\begin{array}{c}100 \% \\
0 \% \\
100 \% \\
0 \% \\
100 \%\end{array}$ \\
\hline $\begin{array}{l}\text { Living Room Air Conditioner } \\
\text { Start-stop }\end{array}$ & $\begin{array}{c}1: 00-6: 00 \\
7: 00-8: 00 \\
9: 00-16: 00 \\
17: 00-21: 00 \\
22: 00-24: 00\end{array}$ & $\begin{array}{c}0 \% \\
100 \% \\
0 \% \\
100 \% \\
0 \%\end{array}$ & $\begin{array}{c}1: 00-7: 00 \\
8: 00-21: 00 \\
22: 00-24: 00\end{array}$ & $\begin{array}{c}0 \% \\
100 \% \\
0 \%\end{array}$ \\
\hline
\end{tabular}

Energy consumption calculation. The heating period is from October 15th to April 15th the next year. The annual total heat load of $205062.61 \mathrm{~kW} \cdot \mathrm{h}$. The annual total heat load index of $124.23 \mathrm{~kW}-$ $\mathrm{h} / \mathrm{m}^{2}$. The whole year hourly load Figure 3 .

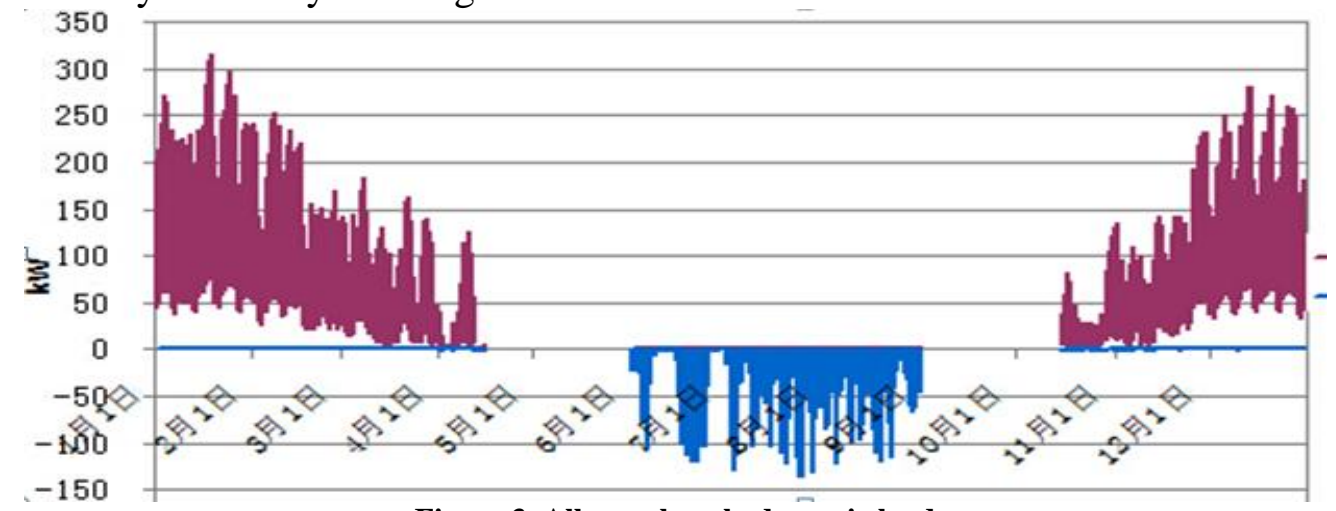

Figure 3 All-year hourly dynamic load 


\section{Analysis on the influence factors of each individual optimization of retaining structure}

Separate different external wall thermal insulation layer. The currently building insulation materials used are EPS foam board, XPS board, rock wool board, polyurethane thermal insulation board and so on. Four kinds of common insulation materials are added in the exterior walls of the building on the base. Exterior insulation scheme is shown in Table 3.

Table 3 Five kinds of exterior insulation scheme

\begin{tabular}{|c|c|c|}
\hline Scheme & Construction & $\begin{array}{c}\text { Heat transfer } \\
\text { coefficient } \\
\mathrm{W} /(\mathrm{m} 2 \cdot \mathrm{K}) \\
\end{array}$ \\
\hline Scheme A & $\begin{array}{c}\text { 20mm Cement mortar }+240 \mathrm{~mm} \text { Multi hole clay brick } \\
+20 \mathrm{~mm} \text { Cement mortar }\end{array}$ & 1.74 \\
\hline Scheme D & $\begin{array}{l}\text { 20mm Cement mortar }+30 \mathrm{~mm} \text { Rock wool board }+240 \mathrm{~mm} \\
\text { Multi hole clay brick }+20 \text { Cement mortar }\end{array}$ & 0.89 \\
\hline Scheme B & $\begin{array}{l}\text { 20mm Cement mortar }+30 \mathrm{mmEPS}+240 \mathrm{~mm} \text { Multi hole } \\
\text { clay brick }+20 \text { Cement mortar }\end{array}$ & 0.81 \\
\hline Scheme C & $\begin{array}{l}\text { 20mm Cement mortar }+30 \mathrm{mmXPS}+240 \mathrm{~mm} \text { Multi hole } \\
\text { clay brick }+20 \text { Cement mortar }\end{array}$ & 0.67 \\
\hline Scheme E & $\begin{array}{l}\text { 20mm Cement mortar }+30 \mathrm{~m} \text { Polyurethane sandwich } \\
\text { panel }+240 \mathrm{~mm} \\
\text { Multi hole clay brick }+20 \mathrm{~mm} \text { Cement mortar }\end{array}$ & 0.64 \\
\hline
\end{tabular}

In addition to wall materials changed, the rest of the parameters are constant. Software simulation of the building heat load is shown in Figure 4.

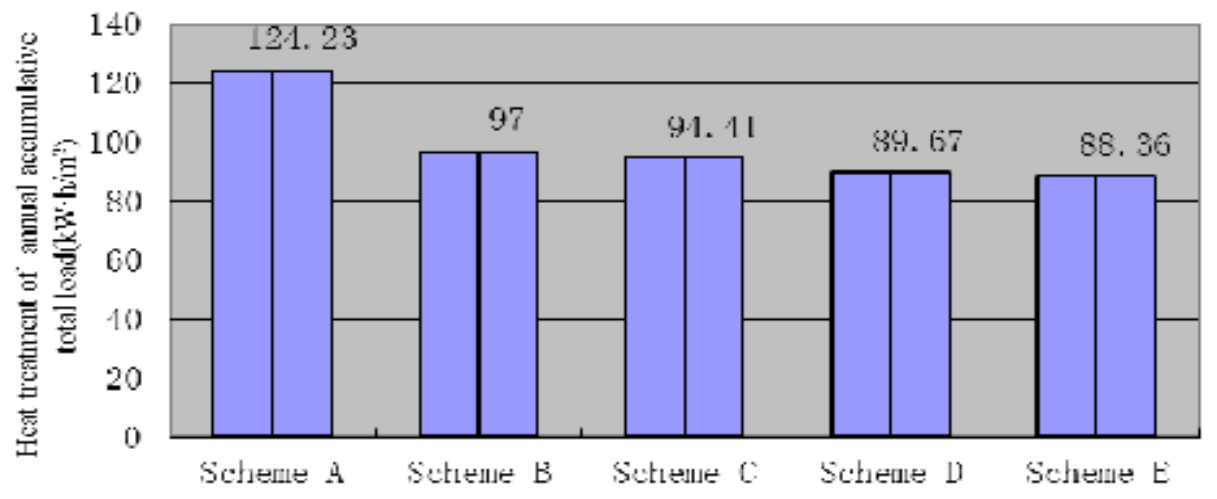

Figure 4 Five plan total heating of the heat load

Observe in Figure 5, the heat transfer coefficient increases linearly with the heating load.The heat transfer coefficient is small, the heating load is small. But at the same time decreased with the load coefficient becomes small and moderate.

By selecting the same insulation materials, changing the thickness of insulation board, the simulation analysis of the relationship between the energy consumption and the thickness of insulation board. In the architectural model is still the benchmark model, the selection of insulation material EPS foam board, all the other parameters are unchanged, the simulation of exterior wall thermal insulation layer is $40 \mathrm{~mm}, 50 \mathrm{~mm}, 60 \mathrm{~mm}, 70 \mathrm{~mm}, 80 \mathrm{~mm}$ thick annual building heat load. Simulation results are shown in Table 4. 
Table 4 Seven kinds of the heat load and relative treatment of annual accumulative total energy saving rate exterior wall thermal insulation layer thickness

\begin{tabular}{ccc}
$\begin{array}{c}\text { Thermal Insulation Layer } \\
\text { Thickness }(\mathrm{mm})\end{array}$ & $\begin{array}{c}\text { The Annual Cumulative Load Index } \\
\left(\mathrm{kW} \cdot \mathrm{h} / \mathrm{m}^{2}\right)\end{array}$ & $\begin{array}{c}\text { The Relative Energy Saving Rate } \\
(\%)\end{array}$ \\
\hline 0 & 124.23 & 0 \\
30 & 94.41 & 24 \\
40 & 90.30 & 27.31 \\
50 & 87.23 & 29.78 \\
60 & 84.86 & 31.69 \\
70 & 82.98 & 33.20 \\
80 & 81.45 & 34.44 \\
\hline
\end{tabular}

Observation of Table 4, with the increase of the thickness of the insulation layer of the wall, the relative energy saving rate continues to increase, but the relative energy saving ratio tends to relax, and not the thickness increases, the relative energy saving ratio is bigger. Application of economic analysis to the insulation layer thickness of a reasonable method to calculate .

Separate different roof insulation layer. Adding four kinds of roof insulation materials based on the benchmark model. Roof insulation scheme is shown in Table 5.

Table 5 Five kinds of roof external thermal insulation

\begin{tabular}{|c|c|c|}
\hline Scheme & Construction & $\begin{array}{c}\text { Heat transfer } \\
\text { coefficient } \mathrm{W} /\left(\mathrm{m}^{2} \cdot \mathrm{K}\right)\end{array}$ \\
\hline Scheme A & $\begin{array}{l}6 \mathrm{~mm} \text { Asphalt Felt }+20 \mathrm{~mm} \text { Cement mortar } \\
+120 \mathrm{~mm} \\
\text { Reinforced concrete roof board }\end{array}$ & 3.468 \\
\hline Scheme B & $\begin{array}{l}6 \mathrm{~mm} \text { Asphalt Felt }+20 \mathrm{~mm} \text { Cement mortar }+30 \mathrm{~mm} \\
\text { Hydrophobic expanded perlite board } \\
\quad+120 \mathrm{~mm} \text { Reinforced concrete roof board }\end{array}$ & 1.766 \\
\hline Scheme C & $\begin{array}{c}\text { 6mm Asphalt Felt }+20 \mathrm{~mm} \text { Cement mortar } \\
+30 \mathrm{mmEPS}+120 \mathrm{~mm} \text { Reinforced concrete roof } \\
\text { board }\end{array}$ & 1.199 \\
\hline Scheme D & $\begin{array}{c}\text { 6mm Asphalt Felt }+20 \mathrm{~mm} \text { Cement mortar } \\
+30 \mathrm{mmXPS}+120 \mathrm{~mm} \text { Reinforced concrete roof } \\
\text { board }\end{array}$ & 0.835 \\
\hline Scheme E & $\begin{array}{c}6 \mathrm{~mm} \text { Asphalt Felt }+20 \mathrm{~mm} \text { Cement mortar }+30 \mathrm{~mm} \\
\text { Polyurethane foam plastic }+120 \mathrm{~mm} \text { Reinforced } \\
\text { concrete roof board }\end{array}$ & 0.776 \\
\hline
\end{tabular}

In addition to the roof material, the other parameters are constant. Software simulation of the building heat load is shown in Figure 5.

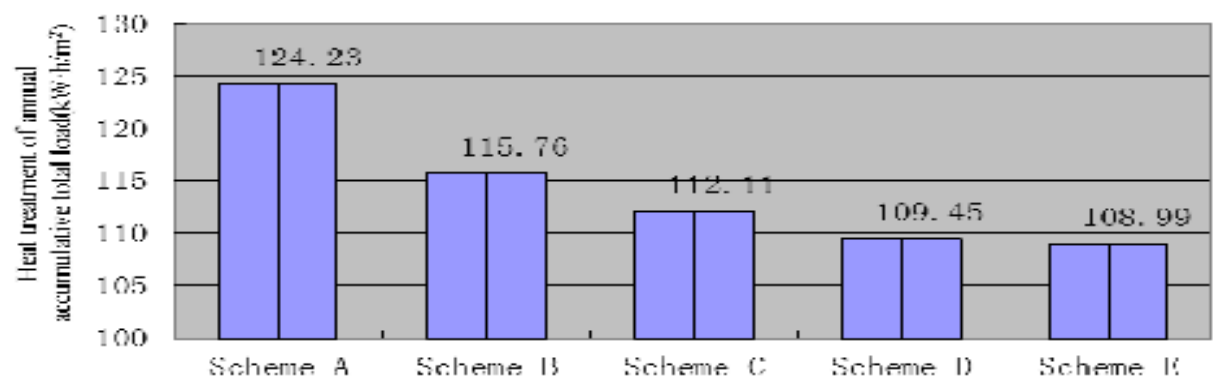

Figure 5 Five plan total heating of the heat load

Observation of Figure 5, adding the roof insulation layer makes the building heat load relative energy saving ratio are increased by $6.82 \%, 9.76 \%, 11.90 \%, 12.27 \%$, rising curve. This shows that the roof with insulation layer, enhance indoor thermal stability and thermal insulation performance and reduce energy consumption. 
Change the window glass. To change the original single glass, for some of the commonly used energy saving glass. Glass solutions is shown in Table 6.

Table 6 Six kinds of glass

\begin{tabular}{|c|c|c|c|}
\hline Scheme & The Category of The Glass & The Glass Layer & $\begin{array}{c}\text { Heat transfer } \\
\text { coefficient } \mathrm{W} /\left(\mathrm{m}^{2} \cdot \mathrm{K}\right) \\
\end{array}$ \\
\hline Scheme A & $\begin{array}{l}\text { Ordinary single-layer glass } \\
\text { Windows }(6 \mathrm{~mm})\end{array}$ & 1 & 5.7 \\
\hline Scheme B & $\begin{array}{c}\text { Ordinary single-layer glass } \\
\text { Windows }\end{array}$ & 2 & 3.1 \\
\hline Scheme C & $\begin{array}{l}\text { Inert gas filled }+ \text { Coated glass } \\
\text { and LOW-E glass }\end{array}$ & 2 & 2 \\
\hline Scheme D & $\begin{array}{l}\text { In a film insulating glass } \\
\text { (mono film) }\end{array}$ & 2 & 1.7 \\
\hline Scheme E & $\begin{array}{l}\text { Vacuum coating composite } \\
\text { insulating glass }\end{array}$ & 3 & 1.4 \\
\hline Scheme F & $\begin{array}{l}\text { In a film insulating glass } \\
\text { (double film) }\end{array}$ & 2 & 1 \\
\hline
\end{tabular}

In addition to the glass changed, the rest of the parameters are constant. Software simulation of the building heat load is shown in Figure 6.

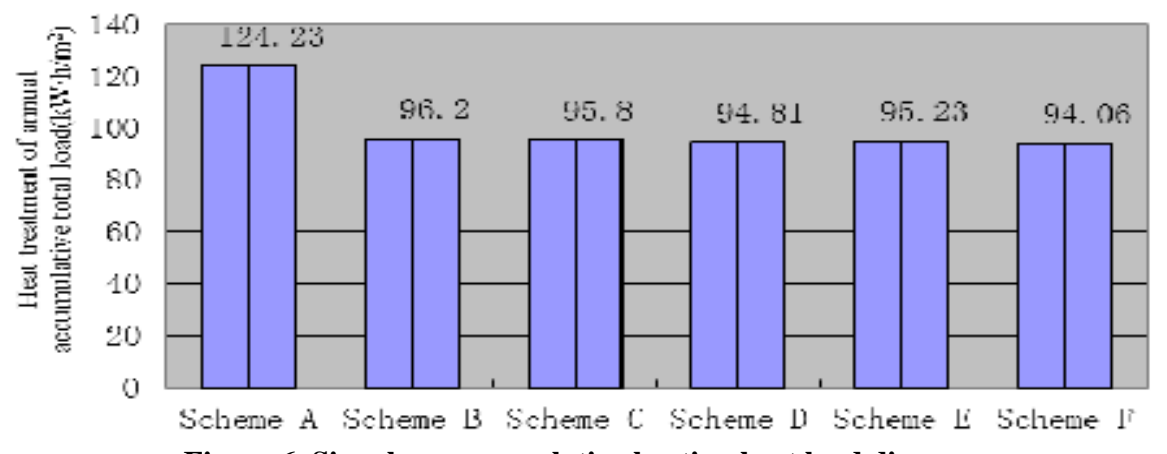

Figure 6 Six schemes cumulative heating heat load diagram

Observe in Figure 6, the heat load of the overall downward trend, but the load index and the window heat transfer coefficient is not a linear relationship. The reason for this is that the heat transfer coefficient is caused by temperature difference of heat flow through the window, it is the conduction, convection and surface radiation heat transfer of the three combination. So energy consumption is related with the shading coefficient of window, visible light transmittance, air permeability.

Change the window wall ratio. When the south window wall ratio is constant, the North window wall ratio increased from 0.3 to 0.6 , the heat load of the heating season has increased by $5.23 \%$, the North outside the window area should be controlled within a proper range to meet the lighting, ventilation and internal requirements.

\section{Conclusion}

On the construction of exterior wall, roof model, window glass, window wall ratio of these four factors separately through the analysis of energy consumption of building energy simulation software DeST, the result is the external wall thermal insulation material and the south window wall ratio on the building heat load impact, windows and roof insulation material second, North window wall ratio is inversely proportional to relationship with the heat load. Therefore, the first energy-saving residential building to strengthen heat preservation effect of exterior wall thermal insulation layer; secondly, the abundant solar energy area, increase the South window wall ratio, as far as possible the use of solar heat radiation, while reducing the North window wall ratio, reduce indoor heat loss; The last is the development and utilization on roof insulation and energy-saving glass. 


\section{References}

[1] JGJ26-2010, design standard for energy efficiency of residential buildings in cold area,China Building Industry Press,Beijing,2010.

[2] Chinese meteorological data for building thermal environment analysis, China Building Industry Press,Beijing, 1979.

[3] Ma Xiuli, Comprehensive energy saving and economic analysis of building structure, J. Sci. 2006 (1):16-18.

[4] Zhang Jinrong,The residential building energy efficiency design of cold region, Shenyang Construction University, Shenyang, 2012. 